\title{
SELECT BIBLIOGRAPHY OF SECONDARY SOURCES
}

Adams, Marilyn McCord, 'Universals in the Early Fourteenth Century', in Kretzmann, Kenny and Pinborg (eds), pp. 411-39.

-William Ockham, 2 vols (Notre Dame: Notre Dame University Press, 1987).

— and P.V. Spade, 'Logic in Late Medieval Oxford', in Catto and Evans (eds), pp. 35-64.

- Some Later Medieval Theories of the Eucharist: Thomas Aquinas, Giles of Rome, and William Ockham (Oxford: Oxford University Press, 2010).

Blumenthal, Uta-Renate, The Investiture Controversy: Church and Monarchy from the Ninth to the Twelfth Century (Philadelphia: University of Pennsylvania Press, 1991).

Boehner, Philotheus, 'The Metaphysics of William Ockham', Review of Metaphysics, 1.4 (1947-48), 59-86.

— 'The Realistic Conceptualism of William Ockham', Traditio, 4 (1946), 307-35.

Boitani, Piero and Anna Torti (eds), Interpretation: Medieval and Modern (Cambridge: D.S. Brewer, 1993).

Breck, Allen du Pont, 'John Wyclyf on Time', in Yourgrau and Breck (eds), pp. $211-17$.

Brown, Stephen F., 'Medieval Supposition Theory in Its Theological Context', Medieval Philosophy and Theology, 3 (1993), 121-57.

Callus, Daniel Angelo Philip (ed.), Robert Grosseteste, Scholar and Bishop: Essays in Commemoration of the Seventh Centenary of His Death (Oxford: Oxford University Press, 1955).

Campi, Luigi, 'Yet Another "Lost" Chapter of Wyclif's "Summa de Ente": Notes on Some Puzzling References to "Tractatus 13", Vivarium, 49:4 (2011), 353-67.

- Was the Early Wyclif a Determinist? Concerning an Unnoticed Level within His Taxonomy of Being', Vivarium, 52 (2011), 102-46.

Catto, Jeremy, 'John Wyclif and the Cult of the Eucharist', $S C h H$, Subsidia, 4 (1985), 269-86.

— 'Some English Manuscripts of Wyclif's Latin Works', SChH, Subsidia, 5 (1987), 353-61.

- 'Wyclif and Wycliffism at Oxford 1356-1430', in Catto and Evans (eds), pp. 175-261.

Catto, Jeremy and T.A.R. Evans (eds), The History of the University of Oxford II: Late Medieval Oxford (Oxford: Oxford University Press, 1992).

Cesalli, L., Le Réalisme Propositionnel: Sémantique et Ontologie des Propositions 
chez Jean Duns Scot, Gauthier Burley, Richard Brinkley et Jean Wyclif(Paris: J. Vrin, 2007).

Colish, Marcia, The Mirror of Language: A Study in the Medieval Theory of Knowledge (New Haven: Yale University Press, 1968).

Medieval Foundations of the Western Intellectual Tradition, 400-1400 (London: Yale University Press, 1997).

— Peter Lombard, 2 vols (Leiden: Brill, 1994).

Copeland, Rita, Rhetoric, Hermeneutics and Translation in the Middle Ages (Cambridge: Cambridge University Press, 1991).

'Rhetoric and the Politics of the Literal Sense in Medieval Literary Theory', in Boitani and Torti (eds), pp. 1-23.

Courtenay, William, 'Antiqui and Moderni in Late Medieval Thought', Journal of the History of Ideas, 48:1 (1987), 3-10, 107-28.

'Force of Words and Figures of Speech: The Crisis over Virtus Sermonis in the Fourteenth Century', Franciscan Studies, 44 (1988 for 1984),

— 'Late-medieval Nominalism Revisited: 1972-1982', Journal of the History of Ideas, 44:1 (1983), 159-64.

- 'Nominalism and Late-medieval Thought: A Bibliographical Essay', Theological Studies, 33 (1972), 716-34.

— 'Nominalism in Late Medieval Religion', in Trinkaus and Oberman (eds), 1974 .

'The Reception of Ockham's Thought in Fourteenth-century England', SChH, Subsidia, 5 (1987), 89-109.

- Schools and Scholars in Fourteenth-century England (Princeton: Princeton University Press, 1987).

'Theology and Theologians from Ockham to Wyclif', in Catto and Evans (eds), pp. 1-34.

Crompton, James, 'Fasciculi Zizaniorum', Journal of Ecclesiastical History, 12 (1961), 35-45, 155-66.

Dahan, Gilbert, L'exégèse chrétienne de la Bible en occident médiéval: XIIe-XIVe siècle (Paris: Les Éditions du Cerf, 2008).

Deansley, Margaret, The Lollard Bible and Other Medieval Versions (Cambridge: Cambridge University Press, 1920).

Dove, Mary, Earliest Advocates of the English Bible: The Texts of the Medieval Debate (Liverpool: Liverpool University Press, 2010).

- The First English Bible: The Text and Context of the Wycliffite Versions (Cambridge: Cambride University Press, 2011).

Dunne, Michael W. and Simon Nolan, O.Carm. (eds), Richard Fitzralph: His Life, Times and Thought (Scarborough: Four Courts Press, 2013).

Evans, G.R. (ed.) Christian Authority: Essays in Honour of Henry Chadwick (Oxford: Oxford University Press, 1988).

- John Wyclif: Myth and Reality (Oxford: Lion Hudson, 2005).

— The Language and Logic of the Bible: The Earlier Middle Ages (Cambridge: Cambridge University Press, 1984).

- The Language and Logic of the Bible: The Road to Reformation (Cambridge: Cambridge University Press, 1985). 
— 'Wyclif on Literal and Metaphorical', SChH, Subsidia, 5 (1987), 259-67.

- 'Wyclif's Logic and Wyclif's Exegesis: The Context', $S C h H$, Subsidia, 4 (1985), 287-301.

Fletcher, J.M., 'Developments in the Faculty of Arts, 1370-1520', in Catto and Evans (eds), pp. 315-45.

Gerrish, B.A. (ed.), Reformers in Profile (Minneapolis: Fortress Press, 1967).

Ghosh, Kantik, The Wycliffite Heresy (Cambridge: Cambridge University Press, 2002).

Gwynn, Aubrey O., The English Austin Friars in the Time of Wyclif(London: Oxford University Press, 1940).

Hammerich, L.L., The Beginning of the Strife between Richard Fitzralph and the Mendicants (Copenhagen: Levin and Munksgaard, 1938).

Haren, Michael, Medieval Thought: The Western Intellectual Tradition from Antiquity to the Thirteenth Century, second edition (London: Macmillan, 1992).

Herold, Vilém, 'Wyclifs Polemik gegen Ockhams Auffassung der platonischen Ideen und ihr Nachlang in der tschechischen hussitischen Philosophie', SChH, Subsidia, 5 (1987), 185-216.

Hornbeck, Patrick, What Is a Lollard? Dissent and Belief in Medieval England (Oxford: Oxford University Press, 2010).

Hudson, Anne, The Premature Reformation: Wycliffite Texts and Lollard History (Oxford: Oxford University Press, 1988).

— 'Wyclif', DMA, vol. 12, pp. 706-11.

—_ 'Wyclif and the English Language', in Kenny (ed.), pp. 85-103.

— 'Wycliffism in Oxford 1381-1411', in Kenny (ed.), pp. 67-84.

Hurley, Michael, “Scriptura Sola”: Wyclif and His Critics', Traditio: Studies in Ancient and Medieval History, Thought and Religion, 16 (1960), 275-352.

Kalivoda, Robert, 'Johannes Wyclifs Metaphysic des Extremen Realismus und Ihre Bedeutung im Endstadium der Mittelalterlichen Philosophie', Miscellanea Mediaevalia, 2 (1963), 716-23.

Keen, Maurice, 'Wyclif, the Bible, and Transubstantiation', in Kenny (ed.), pp. $1-16$.

Kenny, Anthony, 'Realism and Determinism in the Early Wyclif', $S C h H$, Subsidia, 5 (1987), pp. 165-77.

— 'The Realism of the De Universalibus', in Kenny (ed.), pp. 17-31.

-Wyclif(Oxford: Oxford University Press, 1985).

- (ed.), Wyclif in His Times (Oxford: Clarendon Press, 1986).

Kretzmann, Norman, 'Continua, Indivisibles and Change in Wyclif's Logic of Scripture', in Kenny (ed.), pp. 31-65.

Kretzmann, Norman, Anthony Kenny and Jan Pinborg (eds), The Cambridge History of Later Medieval Philosophy (Cambridge: Cambridge University Press, 1982).

Krey, Philip D.W. and Lesley Smith (eds), Nicholas of Lyra: The Senses of Scripture (Leiden: Brill, 2000).

Lahey, Stephen, John Wyclif(Oxford: Oxford University Press, 2009). 
Lambert, Malcolm, Medieval Heresy: Popular Movements from the Gregorian Reform to the Reformation, third edition (Oxford: Blackwell, 2002).

Lampe, G.W.H. (ed.), The Cambridge History of the Bible, II: The West from the Fathers to the Reformation (Cambridge: Cambridge University Press, 1969).

Leff, Gordon, Heresy in the Middle Ages, 2 vols (Manchester: Manchester University Press, 1967).

- 'John Wyclif: The Path to Dissent', Proceedings of the British Academy, 52 (1966), 143-80.

'The Place of Metaphysics in Wyclif's Theology', SChH, Subsidia, 5 (1987), 217-33.

Richard Fitzralph, Commentator on the Sentences (Manchester: Manchester University Press, 1963).

-William of Ockham: The Metamorphosis of Scholastic Discourse (Manchester: Manchester University Press, 1974).

Levy, Ian Christopher (ed.), A Companion to John Wyclif(Leiden: Brill, 2006).

- John Wyclif: Sacriptural Logic, Real Presence, and the Parameters of Orthodoxy

(Milwaukee: Marquette University Press, 2003).

- The Literal Sense of Scripture and the Search for Truth in the Late

Middle Ages', Revue d'Histoire Ecclésiastique, 104:3-4 (2009), 783-827.

Lubac, Henri de, Histoire et Esprit: L'intelligence de l'Écriture d'après Origène (Paris: Aubier, 1950).

— Exégèse médiévale, 4 vols (Paris: Aubier, 1959).

Luscombe, David, Medieval Thought (Oxford: Oxford University Press, 1997).

—_Wyclif and Hierarchy', SChH, Subsidia, 5 (1987), 233-45.

Macy, Gary, The Banquet's Wisdom: A Short History of the Theologies of the Lord's

Supper, second edition (Ashland City, TN: OSL Publications, 2005).

'The Dogma of Transubstantiation in the Middle Ages', Journal of Ecclesiastical History, 45:1 (1994).

Mallard, William, 'John Wyclif and the Tradition of Biblical Authority', Church History, 30 (1961), 50-60.

Marenbon, John, Early Medieval Philosophy, 480-1150: An Introduction(London: Routledge, 1984).

— Later Medieval Philosophy 1150-1350: An Introduction (London: Routledge, 1987).

- Medieval Philosophy: An Historical and Philosophical Introduction (London: Routledge, 2007).

Martin, C.J.F., An Introduction to Medieval Philosophy (Edinburgh: Edinburgh University Press, 1996).

— The Philosophy of Robert Grosseteste (Oxford: Clarendon Press, 1982).

McFarlane, K.B., John Wyclif and the Beginnings of English Non-conformity (London: English Universities Press, 1952).

Minnis, A. J. “Authorial Intention" and "Literal Sense" in the Exegetical Theories of Richard Fitzralph and John Wyclif', Proceedings of the Royal Irish Academy, lxxv, section C, i (1975), 1-31.

'Exegesis, Latin', in DMA, vol. 4, pp. 542-5.

— 'Exegesis, Middle English', in $D M A$, vol. 4, pp. 545-8 
— Medieval Theory of Authorship, second edition with a new preface by the author (Philadelphia: University of Pennsylvania Press, 2010).

— and A.B. Scott (eds), Medieval Literary Theory and Criticism, c. 1100-c. 1975: The Commentary Tradition, revised edition (Oxford: Clarendon Press, 1991). Müller, Ivan J., 'A “Lost” Summa of John Wyclif', SChH, Subsidia, 5 (1987), $179-85$.

Normore, Calvin, 'The Tradition of Medieval Nominalism', in Wippel (ed.), pp. $201-17$.

Oberman, Heiko A., Forerunners of the Reformation (Lutterworth: Lutterworth Press, 1967).

— The Harvest of Medieval Theology: Gabriel Biel and Late Medieval Nominalism, third edition (Durham, NC: Labyrinth Press, 1983).

- 'Some Notes on the Theology of Nominalism, with Attention to Its Relation to the Renaissance', Harvard Theological Review, 53 (1960), 47-76.

Pantin, W.A., The English Church in the Fourteenth Century (Notre Dame: University of Notre Dame Press, 1962).

Pasnau, Robert, with Christina van Dyke (eds), The Cambridge History of Medieval Philosophy, 2 vols (Cambridge: Cambridge University Press, 2014).

Penn, Stephen, 'Matrimonium quid proprie sit: John Wyclif on Marriage, Consent and Consummation', in Archa Verbi, Subsidia, 15 (2018), ed. Pavel Blazek, pp. 399-411.

— 'Wyclif and the Sacraments', in Levy (ed.), pp. 241-92.

Rijk, L.M. de, Logica Modernorum: A Contribution to the History of Early Terminist Logic (Assen: H.J. \& H.M.G. Prakke, 1962-67).

Robson, J.A. Wyclif and the Oxford Schools: The Relation of the Summa de Ente to Scholastic Debates in Fourteenth-century Oxford (Cambridge: Cambridge University Press, 1961).

Saul, Nigel, Richard II (London: Yale University Press, 1997).

Smalley, Beryl, 'The Bible and Eternity: John Wyclif's Dilemma', JWCI, 27 (1964), 73-89.

—_John Wyclif's Postilla super Totam Bibliam', Bodleian Library Record, 4 (1953), 186-204.

- The Study of the Bible in the Middle Ages, third edition (Oxford: Blackwell, 1983).

Southern, R.W., Robert Grosseteste: The Growth of an English Mind in Medieval Europe, second edition (Oxford: Clarendon, 1986).

Synave, P. 'La Doctrine de Saint Thomas d'Aquin sur le Sens Littéral des Écritures', Revue Biblique, 35 (1926), 40-65.

Thomson, S.H. 'John Wyclyf' in Gerrish (ed.), pp. 12-39.

— 'The Order of Writing of Wyclif's Philosophical Works', in Českou Minulostí práce, věnované professoru Karlovy university Václavu Novotnému, ed. O. Odložilík, J. Prokeš and R. Urbánek (Prague: J. Laichter, 1929), pp. 146-66.

'The Philosophical Basis of Wyclif's Theology', Journal of Religion, 11 (1931), 86-116. 
- The Writings of Robert Grosseteste, Bishop of Lincoln 1235-1253 (Cambridge: Cambridge University Press, 1940).

Thomson, Williell R., The Latin Writings of John Wyclif: An Annotated Catalog (Toronto: Pontifical Institute of Mediaeval Studies, 1983).

'Manuscripta Wyclifiana Desiderata: The Potential Contribution of Missing Latin Texts to Our Image of Wyclif's Life and Works', $S C h H$, Subsidia, 5 (1987), 343-53.

Trinkaus, Charles, with Heiko A. Oberman (eds), The Pursuit of Holiness in Late Medieval and Renaissance Religion (Leiden: Brill, 1972).

Walsh, Katherine, A Fourteenth-century Scholar and Primate: Richard Fitzralph at Oxford, Avignon and Armagh (Oxford: Oxford University Press, 1981).

Wilks, M.J., 'The Early Oxford Wyclif: Papalist or Nominalist?', SChH, 5 (1969), 69-98.

_ 'Roman Candle or Damned Squib? The English Crusade of 1383', an inaugural lecture delivered in 1980 at Birkbeck, University of London, and reproduced in Wyclif: Political Ideas and Practice, selected and introduced by Anne Hudson (Oxford: Oxbow Books, 2000), pp. 253-72.

Workman, Herbert. John Wyclif: A Study in the English Medieval Church, 2 vols (Oxford: Oxford University Press, 1926).

Yourgrau, Wolfgang and Allen D. Breck (eds), Cosmology, History and Theology (New York: Plenum Press, 1977). 